\title{
High power laser use in the COVID-19 pandemic era in dentistry: tips for the readers
}

\author{
Marcus Vinicius Lucas Ferreira ${ }^{1}$ (D) $\cdot$ Leandro Napier de Souza ${ }^{1}$
}

Received: 18 June 2020 / Accepted: 5 August 2020 / Published online: 9 August 2020

(C) Springer Nature Switzerland AG 2020

Coronavirus disease 2019 (COVID-19) pandemic caused by the severe acute respiratory syndrome coronavirus 2 (SARSCoV-2) has brought new challenges to dental practice. Although elective procedures should not be performed during this time, urgency and future treatment guidelines must be established for safe management of dental patients and protection of the professional staff [1].

High power lasers (HPLs) are used to perform soft tissue surgery and other dental procedures such as caries removal, root decontamination, and bone surgery. Some of these lasers, for example, Er,Cr:YSGG, Er:YAG, and CO2 $(9.3 \mu \mathrm{m})$, use an air-water spray as a cooling system, which may certainly produce aerosols. Other HPLs such as diode lasers, Nd:YAG, and $\mathrm{CO} 2(10.3 \mu \mathrm{m}$ and $10.6 \mu \mathrm{m})$ do not have a water cooling system and are used mainly in soft tissue surgery and dental decontamination. The interaction of these lasers with biologic tissues produces surgical smoke capable of carrying virus particles, such as human immunodeficiency virus (HIV) [2] and human papillomavirus (HPV) [3].

Dentists should be aware of safety rules and other procedures that can diminish the possibility of contamination during aerosol generation. For operative dentistry, the use of a rubber dam must be mandatory. Special care must be taken when choosing the dental clamp. According to laser safety rules, the clamp should not produce specular reflection. Therefore, a plastic, anti-reflective, or even a sandblasted clamp must be used. A less reflective clamp minimizes accidental reflection during laser irradiation. The rubber dam sheet color should not be dark, particularly black. A dark rubber dam can intensely absorb the energy produced by laser, and this could pierce or tear the dam if it were irradiated accidentally instead of the enamel or dentin.

Marcus Vinicius Lucas Ferreira mvlucas@uol.com.br

1 School of Dentistry, Universidade Federal de Minas Gerais, Belo Horizonte, Minas Gerais, Brazil
In all procedures, irrespective of the laser production, a high vacuum aspiration system (HVAC) must be used directly pointed towards the air-water spray or to the smoke to prevent it from spreading and risking contamination resulting from the aerosolized particles $[4,5]$.

According to the new biosafety standards, considering the imminent risk of performing procedures in asymptomatic or presymptomatic patients, a face shield must be worn by dental staff during dental procedures. The choice of a facial shield must take into account the space between the shield and the eyes; it must allow the correct adaptation of the laser safety glasses. The safety glasses must be properly decontaminated after each procedure. In addition, an appropriate fitted N-95 mask should be worn to protect the dentist from inhaling the aerosolized particles and smoke that escapes from the HVAC [6].

Furthermore, dentists should prefer laser systems used with disposable optic fiber tips whenever possible. If not available, laser handpieces must be sterilized after each use. New insights or scientific evidence could allow us to improve the biosafety measures and prevent cross contamination when dealing with new infectious diseases such as COVID-19.

\section{Compliance with ethical standards}

Conflict of interest The authors declare that they have no conflict of interest.

Ethical approval The authors declare that they do not need the ethical approval from any committee.

\section{References}

1. Halepas S, Ferneini EM (2020) A pinch of prevention is worth a pound of cure: proactive dentistry in the wake of COVID-19. J Oral Maxillofac Surg 78:860-861. https://doi.org/10.1016/j.joms. 2020.03.036

2. Baggish MS, Poiesz BJ, Joret D, Williamson P, Refai A (1991) Presence of human immunodeficiency virus DNA in laser smoke. 
Lasers Surg Med 11:197-203. https://doi.org/10.1002/1sm. 1900110302

3. Gloster HM Jr, Roenigk RK (1995) Risk of acquiring human papillomavirus from the plume produced by the carbon dioxide laser in the treatment of warts. J Am Acad Dermatol 32(3):436-441. https:// doi.org/10.1016/0190-9622(95)90065-9

4. Civantos FJ, Leibowitz JM, Arnold DJ, Stubbs VC, Gross JH, Thomas GR, Sargi Z, Casiano RR, Franzmann EJ, Weed D, Perez C, Samuels M, Goodman KW, Goodwin WJ (2020) Ethical surgical triage of head and neck cancer patients during the COVID-19 pandemic. Head Neck 42:1423-1447. https://doi.org/10.1002/hed. 26229
5. Thamboo A, Lea J, Sommer DD, Sowerby L, Abdalkhani A, Diamond C, Ham J, Heffernan A, Cai Long M, Phulka J, Wu YQ, Yeung P, Lammers M (2020) Clinical evidence based review and recommendations of aerosol generating medical procedures in otolaryngology-head and neck surgery during the COVID-19 pandemic. J Otolaryngol Head Neck Surg 49:28. https://doi.org/10. 1186/s40463-020-00425-6

6. Howard J, Huang A, et al. (2020). Face masks against COVID-19: an evidence review. https://doi.org/10.20944/preprints202004.0203.v1

Publisher's note Springer Nature remains neutral with regard to jurisdictional claims in published maps and institutional affiliations. 